УДК 340.12:327

DOI https://doi.org/10.32837/yuv.v0i1.2087

\author{
Н. Загребельна, \\ кандидат юридичних наук, \\ методист другої категорії навчально-методичного відділу навчального процесу \\ Інституту післядипломної освіти \\ Київського національного університету імені Тараса Шевченка
}

\title{
ЮРИДИЧНА ПРИРОДА І СОЦІАЛЬНА НЕОБХІДНІСТЬ ЗАБЕЗПЕЧЕННЯ ПРАВ ЛЮДИНИ В УМОВАХ НАДЗВИЧАЙНОГО СТАНУ
}

Науковий підхід до дослідження будь-яких об’єктів правової дійсності неможливий без глибокого аналізу всіх його сторін з метою виявлення сутності такого об'єкта. Своєю чергою розуміння суті, відповідно до філософського трактування, неможливе без постановки питання про джерела i причини походження явища, тобто про його природу.

Дослідження явищ правової дійсності, наприклад юридичних норм, традиційно здійснюється за двома основними напрямами: дослідження такого явища в світі зумовленості суспільними факторами, тобто у соціальному сенсі, і дослідження форм і способів створення і функціонування цих норм (у формальному сенсі). Як правило, основна увага в науковій літературі приділяється саме останньому аспекту, де дослідженню піддаються різні види правових актів, правові звичаї і судові прецеденти [1, с. 152].

Разом із тим отримання найбільш чіткого й об'єктивного уявлення про природу будь-якого правового явища неможливе з використанням тільки формально-юридичного підходу. Соціальна зумовленість багатьох аспектів права змушує неминуче звертатися в ході дослідження саме до цього складника.

Особливо актуальним стає застосування соціологічного підходу під час дослідження природи такого об’єкта, як права і свободи людини. Джерела i причини його походження нерозривно пов'язані із суспільними явищами, історичними подіями та політичними умовами. Також нерозривно пов'язані з ними і проблеми обмеження прав і свобод людини, оскільки необхідність у цьому випливає з неоднорідності соціуму, а також тих відносин, які в ньому виникають.

Застосування соціологічного підходу також $є$ ефективним у разі дослідження такого специфічного виду обмеження прав людини, як обмеження в умовах особливих надзвичайних режимів, що вводяться державою для усунення найбільш масштабних загроз громадському благополуччю.

Соціологічний напрям у правовій науці отримав натепер велике поширення. Ï̈́̈ засновники - австрійський учений Е. Ерліх $\mathrm{i}$ американський Р. Паунд - поклали в основу свого вчення ідею про те, що джерелом права не є законотворчість або судові прецеденти, а самі цивільні відносини.

Виходячи з усього вищесказаного, необхідно відзначити, що всебічне і повне дослідження правових явищ, особливо стосовно регулювання прав людини, необхідно проводити в двох основних напрямах - виявлення його юридичної природи і розкриття соціальних процесів, що його зумовлюють.

3 початку XX століття процеси міжнародної взаємодії пройшли великий i тернистий шлях до створення 
нинішньої наднаціональної системи норм, що регулюють відносини спеціальних суб'єктів - держав, державно-подібних утворень, націй, міжнародних організацій. Саме у цей час міжнародне право повною мірою звертається до питань забезпечення прав людини, виводячи цю сферу з виняткового ведення держав. Основні права людини, їі волі і природні потреби виводяться міжнародним правом на перше місце в переліку пріоритетів цивілізованого світу. До кінця $\mathrm{XX}$ століття проблеми міжнародноправового захисту прав людини стали одними $з$ найбільш буденних.

Особливою сферою у цьому питанні $є$ забезпечення прав людини в кризових ситуаціях - війнах, збройних конфліктах, у разі масових заворушень, збройних повстань, природних і техногенних лих. Міжнародне право не обійшло стороною і ці проблеми, створивши нормативну базу для цивілізованої поведінки держав щодо усунення наслідків кризових ситуацій.

Таким чином, наднаціональне регулювання стосовно тематики цього дослідження охоплює принаймні два аспекти:

1) регулювання i захист прав людини;

2) регулювання питань, пов'язаних 3 виникненням кризових ситуацій внутрішнього характеру.

У міжнародному праві $€$ широко визнане положення про те, що права людини і основні свободи як загальне правило повинні дотримуватися як у мирний час, так i в період надзвичайних обставин і збройних конфліктів. Зазвичай норми про права людини застосовуються в нормальних ситуаціях і підлягають тільки окремим обмеженням, пов'язаним із забезпеченням національної безпеки, підтриманням громадського порядку і дотриманням моральних норм [2, с. 101].

Згідно 3 міжнародним правом, коли рівень заворушень стає досить високим і вони починають загрожу- вати існуванню націі, отже, дотриманню прав основної маси населення, держави, відповідно до права прав людини, можуть оголосити надзвичайний стан і відступити від виконання своїх зобов'язань з прав людини, якщо вони зуміють довести, що відступ $€$ необхідним i що прийняті кроки відповідні загрозі державі або прав інших.

Коли загострення ситуації призводить до збройного конфлікту, норми, викладені у статті 3 Женевської конвенції 1949 року, вступають у дію і накладають певні зобов'язання, що стосуються найістотніших питань, на всі сторони в конфлікті. Вони у загальному аналогічні положенням права прав людини, від яких, відповідно до основних договорів з прав людини, неприпустимі відступи: зокрема, це зобов'язання гуманно поводитися з особами, котрі беруть участь у конфлікті [2, с. 106].

Однією 3 найважливіших проблем $є$ проблема діяльності правоохоронних органів $з$ питань охорони, захисту i дотримання прав і свобод людини і громадянина, що ставить перед юридичною наукою і практикою низку конкретних завдань, пов'язаних 3 необхідністю дослідження забезпечення прав і свобод людини. Забезпечення прав людини в обставинах, у разі яких є безпосередня загроза життю та безпеці людини, загроза насильницькій зміні конституційного ладу країни, веде до застосування надзвичайного законодавства, до деяких обмежень прав і свобод громадян, а також і до захисту прав людини [2, с. 109].

Перший напрям передбачає інтереси людини в період, коли їі права i свободи стають найбільш вразливими (збройний заколот, масові заворушення, терористичні акти, блокування або захоплення особливо важливих об'єктів або окремих місцевостей, підготовка і діяльність незаконних збройних формувань, що супроводжуються насильницькими 
діями, створюють безпосередню загрозу життю i безпеці громадян, нормальній діяльності органів державної влади, а також надзвичайні ситуації природного i техногенного характеру).

Другий напрям відображає інтереси держави щодо нормалізації обстановки всередині країни до прийнятного рівня законності і порядку (заходи щодо захисту життя і здоров'я громадян). Першим зробив неоціненний внесок у розробку теорії надзвичайного законодавства вчений B.M. Гессен. Він запропонував розуміти, що надзвичайний стан - сукупність виняткових повноважень, у чому б вони не перебували, що надаються урядовою владою у разі настання обставин, що загрожують зсередини або ззовні існуванню держави [3].

Вчений С.К. Могил дає таке трактування: надзвичайне законодавство являє собою комплекс нормативноправових актів, за допомогою яких правове регулювання здійснюється в умовах надзвичайної обставини. Надзвичайне законодавство, відображаючи універсальний характер права, може бути не тільки ефективним засобом захисту конституційних прав, але і могутньою зброєю насильства в руках держави. Основна соціальна причина застосування надзвичайних заходів неминуче супроводжується обмеженнями прав і свобод людини, полягає в необхідності відновлення правового, економічного чи політичного стану. Це дозволяє громадянину і суспільству реалізовувати свої права в тому обсязі і на тих умовах, які існували до виникнення надзвичайних обставин, що стали підставою для застосування надзвичайного законодавства, що обмежує права і свободи громадянина [4, с. 39].

Ієрархічність надзвичайного законодавства у галузі забезпечення прав людини в умовах надзвичайних обставин виражається в тому, що джерелами формування виступають різні за юридичною силою нормативні акти, що утворюють свого роду правову піраміду.

Загальна декларація прав людини 1948 р. закріпила основні права і свободи, передбачаючи можливість ї обмеження [5]. 3 цього документа можна виділити дві основні умови обмеження прав: тільки по закону i в цілях забезпечення реалізації правомірних особистих i державних інтересів. Обмеження прав людини мають вимушений і природний характер поряд $з$ їх захистом. Міжнародне право також не виключає обмеження прав людини.

Зокрема, Загальна декларація прав людини 1948 р. у ст. 29 вказує, що у разі здійснення своїх прав і свобод кожна людина повинна зазнавати тільки таких обмежень, які встановлені законом виключно з метою забезпечення належного визнання і поваги прав і свобод інших та забезпечення справедливих вимог моралі, громадського порядку і загального добробуту в демократичному суспільстві [5].

Міжнародний пакт про громадянські і політичні права 1966 р. [6] конкретизує загальні цілі обмеження прав людини, передбачені Загальною декларацією прав людини, вводячи в обіг поняття «охорона державної безпеки» [6]. Наявність у нормі такої правової конструкції дозволяє не виводити право держави на обмеження прав людини в умовах надзвичайного стану зі змісту статті, а безпосередньо констатувати закріплення такої можливості, оскільки охорона державної безпеки завжди має на увазі як звичайні, так і виняткові засоби; обмеження або відступу від загальних зобов'язань у разі настання надзвичайних обставин.

Відповідно до Пакту обмеження допускаються лише такою мірою, якою це потрібує у разі гостроти становища. Такого роду дії не повинні спричинити собою дискримінацію на основі раси, кольору шкіри, статі, мови, релігії чи соціального походження. 
Разом із тим у Пакті про громадянські і політичні права [6] зазначається, що здійснення деяких прав навіть в умовах дії режиму надзвичайного стану (обставини) не повинне припинятися або обмежуватися. Аналогічна норма представлена і в регіональних актах.

Європейська конвенція про захист прав людини і основних свобод 1950 р. закріпила право на життя, свободу від катувань, свободу від рабства, захист від ув'язнення за несплату боргу, захист від кримінальних законів, що мають зворотну силу, свободу совісті, думки, релігї.

У міжнародних актах перелік прав і свобод людини недостатній. Держави у своїх національних актах інших подібних рішень закріплюють набагато ширший перелік прав і свобод, які не підлягають обмеженню в період дії надзвичайного стану. До числа прав і свобод, які не можуть бути обмежені в умовах надзвичайного стану (обставини), Пакт про громадянські і політичні права відносить виключно особисті (цивільні) права і свободи, що може розглядатися як одна 3 гарантій дотримання принципу невтручання в справи, що становлять по суті внутрішню компетенцію держави.

У міжнародно-правовому регулюванні із забезпечення прав людини в умовах надзвичайного стану виступає те, що Міжнародний пакт «Про громадянські та політичні права» 1966 року та Європейська конвенція про захист прав людини і основних свобод 1950 р. закріплюють обов'язок держав негайно інформувати інші держави, які беруть участь у цих актах, за посередництвом Генерального секретаря Організації Об'єднаних Націй $(\mathrm{OOH})$ та Генерального секретаря Ради Європи про положення, від яких вона відступила, і про причини, що передували прийняттю такого рішення.

Також має бути зроблено повідомлення через того ж посередника про дату, коли воно припиняє такий від- ступ. Разом із тим вимога щодо повідомлення про введення надзвичайного стану, на відміну від вимоги про його офіційне оголошення, не $є$ необхідною умовою для обгрунтування введення заходів надзвичайного характеру. Воно служить тому, щоб полегшити міжнародний контроль як з боку інших держав, так і Комітету ООН $з$ прав людини.

Міжнародна Організація Об'єднаних Націй $(\mathrm{OOH})$ створена для підтримки і зміцнення міжнародного миру і безпеки, розвитку співпраці між державами. ООН наділена правом вживати заходи для захисту прав людини в період надзвичайних обставин.

Регіональна міжурядова організація на європейському континенті Рада Європи та їі організації. Зокрема, серед завдань, які стоять перед Комітетом міністрів Ради Європи, закріплене завдання щодо захисту демократичних процедур і прав людини в Європі. Комітет міністрів має право вживати заходів, спрямованих на досягнення цілей Ради Європи, а також на реалізацію рекомендацій Парламентської Асамблеї (ПАРЄ).

Неурядова міжнародна гуманітарна організація Міжнародний Комітет Червоного Хреста (МКЧХ), що здійснює свою діяльність у всьому світі, має велику практику з надання захисту прав людини i надання допомоги особам, які постраждали в результаті заворушень і напруги всередині країни. Держави всього світу ніколи не ставили під сумнів сам принцип нейтральності та неупередженості, на якому заснована така практика. Підстава для діяльності МКЧХ в обстановці масових заворушень i внутрішнього збройного конфлікту та інших надзвичайних обставин набула характеру звичаю. Разом із тим на міжнародному рівні не закріплені відповідні зобов'язання національних урядів - приймати подібні пропозиції від неурядових організацій. 
Найбільша у світі регіональна Організація з Безпеки та Співробітництва в Європі (ОБСЄ) об'єднує 57 країн, розташованих в Європі, Північній Америці і Центральній Азії.

До основних завдань належать:

1) захист прав людини;

2) розвиток демократичних інститутів;

3) моніторинг виборів [7].

Надзвичайне законодавство, як i звичайне, володіє системністю та ієрархічністю. Основним системоутворюючим фактором виступає об'єкт правового впливу - інтереси особи, суспільства і держави в надзвичайних обставинах.

Особливістю надзвичайного законодавства є те, що його реалізація здійснюється за допомогою виконання певних функцій усіма гілками влади на різних управлінських рівнях. Більшою мірою це стосується таких органів виконавчої влади, як Міністерство оборони України, МВС України, МНС України.

В Україні проблема гарантій конституційних прав і свобод людини і громадянина в забезпеченні надзвичайного законодавства вельми актуальна. Під правовими гарантіями слід розуміти умови і правові засоби, які реально забезпечують людині і громадянину можливість користуватися основними правами і свободами, а також неухильно виконувати покладені на них обов'язки [8, с. 33].

Сучасне надзвичайне законодавство України насамперед засноване на загальновизнаних принципах i нормах міжнародного права, а також на міжнародних договорах, які $є$ складовою частиною іiі правової системи, основу якої становлять імперативні норми, що являють собою його основні принципи. Конституція України безпосередньо пов'язує введення надзвичайного стану з можливістю обмеження прав людини, визнаючи такий факт неминучим наслідком введення такого режиму.
У статті досліджено юридичну природу $i$ соиіальну необхідність забезпечення прав людини в умовах надзвичайного стану. Автор зверmaє увагу на те, що нестабільність політичної обстановки, економічна i соціальна кризи у суспільстві, зростання злочинності, правовий нігілізм, екологічні лиха $i$ багато інших негативних процесів, що протікають у сучасній Україні, прямо і побічно продукують екстремальні ситуаціі. Адміністративно-правовий режим надзвичайного стану досить складний $i$ багатогранний конституиійний інститут, дослідження $і$ розвиток якого актуальне нині не тільки для України, а й для більшості держав світу. Тероризм i стихійні лиха, державні перевороти $і$ міжнаціональні конфлікти, епідеміі $i$ епізоотії не можуть не становити небезпеку для держави з будь-якою формою державної влади $i$ управління, політичного режиму $i$ релігійної спрямованості. Тим більше актуальні такі проблеми в умовах недостатньої підготовленості органів державної влади та місиевого самоврядування до екстреного і інтенсивного реагування на них в умовах надзвичайної ситуації, найчастіше зумовленої дією не одного, а иілої сукупності вищеназваних чинників. Насамперед для дослідження, яке зачепило таке коло проблем, провідне значення має вивчення правової бази, яка повинна регламентувати в деталях усі необхідні елементи процесу усунення обставин, що спровокували виникнення екстремальної ситуації на території держави. Чітка регламентація дій суб’єктів, що відповідають за введення $i$ підтримання режиму надзвичайного стану, є запорукою ефективної боротьби з раптовим непередбаченим явищем політичного, екологічного, техногенного чи іншого характеру. Актуальною у сучасних умовах є проблема 
забезпечення прав і свобод людини $i$ громадянина в умовах режиму надзвичайного стану. Особа людини, ї основні права $і$ законні інтереси натепер далеко не завжди захищені в реальному житті держави i суспільства, тим більше, в екстремальних умовах. Теоретичною основою вивчення питань порядку та підстав уведення правового режиму надзвичайного стану стали публікації таких провідних науковців, як: В.В. Кожан, C.O. Магда, C.K. Могил, Б.I. Сmaхура, T.М. Шмідт та ін.

Ключові слова: надзвичайний стан, умови надзвичайної ситуації, права і свободи людини і громадянина, політичний режим, демократичне суспільство.

Zahrebelna $\mathbf{N}$. Legal nature and social necessity of ensuring human rights in a condition of emergency

The article examines the legal nature and social necessity of ensuring human rights in a state of emergency. The author draws attention to the fact that the instability of the political situation, economic and social crises in society, rising crime, legal nihilism, environmental disasters and many other negative processes taking place in modern Ukraine, directly and indirectly produce extreme situations. The administrative and legal regime of the state of emergency is a rather complex and multifaceted constitutional institution, the research and development of which is relevant today not only for Ukraine, but also for the vast majority of countries in the world. Terrorism and natural disasters, coups and ethnic conflicts, epidemics and epizootics cannot but pose a danger to the state with any form of government and governance, political regime and religious orientation. These problems are even more relevant in the conditions of insufficient preparation of public authorities and local governments for emergency and intensive response to them in an emergency, often due to the action of not one but a whole set of the above factors. First of all, for the study, which touched upon this range of problems, the study of the legal framework is of paramount importance, which should regulate in detail all the necessary elements of the process of eliminating the circumstances that provoked the extreme situation in the state. Clear regulation of the actions of the entities responsible for the introduction and maintenance of the state of emergency is the key to an effective fight against sudden unforeseen phenomena of political, environmental, man-made or other nature. The problem of ensuring the rights and freedoms of man and citizen in a state of emergency is relevant in modern conditions. The human person, his fundamental rights and legitimate interests today are not always protected in the real life of the state and society - especially in extreme conditions. The theoretical basis for studying the order and grounds for the introduction of the legal regime of the state of emergency were the publications of such leading scholars as: V.V. Kozhan, S.O. Magda, S.K. Mogil, B.I. Stakhura, T.M. Schmidt etc.

Key words: state of emergency, conditions of emergency, human and civil rights and freedoms, political regime, democratic society.

\section{Література}

1. Магда С.О. Про иілі обмеження прав і свобод громадян в умовах надзвичайних адміністративно-правових режимів. Науковий вісник Дніпропетровського державного університету внутрішніх справ. 2007. № 3(34). С. 152-158.

2. Шмидт Т.М. Чрезвычайное правовое регулирование: общетеоретическое исследование : дис. канд. юрид. наук : 12.00.01. Белгород, 2014. 191 c. 


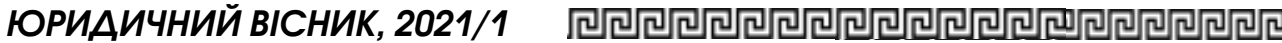

3. Cтахура Б.I. Роль органів державної влади у забезпеченні прав людини $i$ громадянина в демократичному суспільстві: теоретико-правовии вимір : дис. канд. юрид. наук: 12.00.01. Львів, 2016. $180 \mathrm{c}$

4. Могил С.К. Государство в предупреждении и ликвидаиии последствий аварий и катастроф. Актуальні проблеми держави і права: зб. наук. пр. Bun. 6, 4. II. Oдеса : Acmponpuнm, 1999. C. 107.

5. Загальна декларація прав людини від 10 груд. 1948 р. Голос України. 2008. № 236. C. 15-17.
6. Міжнародний пакт про громадянські та політичні права. URL: http:// zakon2.rada.gov.ua/laws/show/995_043.

7. Організаиія з безпеки і співробітниитва в Європі. Опубліковано 23 жовтня 2019 року. URL: https://mfa.gov.ua/ mizhnarodni-vidnosini / organizaciya-z-bezpeki-i-spivrobitnictva-v-yevropi.

8. Кожан В.В. Теоретичні основи $і$ практика законодавчого закріплення особистих прав людини. Науковий вісник Міннародного гуманітарного універcumeту. Серія «Юриспрудениія». 2015. № 18. C. 33-36.

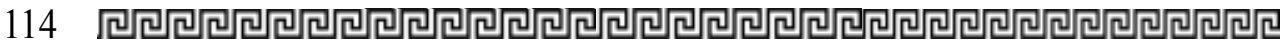

